\title{
APONTAMENTOS SOBRE AS POLÍTICAS PÚBLICAS DE COMBATEÃ SECA NO BRASIL: CISTERNAS E CIDADANIA?
}

\section{RESUMO}

A cisterna é uma forma milenar de armazenamento de água das chuvas em regiões que não dispõem de fonte de água permanente, como o Semiárido Nordestino do Brasil, possibilitando à população obter água limpa e fácil de tratar. Este artigo apresenta considerações preliminares sobre o levantamento das políticas públicas criadas para resolver o problema da seca no Nordeste - desde a criação da Inspetoria Federal de Obras Contra as Secas (IFOCS) ainda no Império, até o Programa 1 Milhão de Cisternas (P1MC), lançado pelo presidente Lula em 2003. O Programa surgiu da iniciativa da Articulação do Semiárido (ASA), ONG que atualmente envolve cerca de 700 entidades. O trabalho analisa especificamente a influência da utilização das cisternas nas condições de vida das famílias na região da bacia do Baixo Salitre, município de Juazeiro, na Bahia. Para tanto, foram realizadas 34 entrevistas com famílias dessa região, e os resultados obtidos sinalizam que a utilização de cisternas influencia positivamente a qualidade de vida dessas famílias, na saúde, no tempo livre, na renda, e na questão de gênero. Até 2009, foram construídas mais de 266 mil cisternas, mobilizando 292 mil famílias, em 6.078 municípios.

PALAVRAS-CHAVE Política pública, cidadania, parcerias, Semiárido Brasileiro, desenvolvimento local.

Claudia Souza Passador cspassador@usp.br

Faculdade de Economia, Administração e Contabilidade de Ribeirão Preto - FEA-RP/USP. Professora Doutora e Coordenadora do Centro de Estudos de Gestão e Políticas Públicas Contemporâneas (GPUBLIC).

João Luiz Passador jlpassador@usp.br

Faculdade de Economia, Administração e Contabilidade de Ribeirão Preto - FEA-RP/USP. Professor Doutor.

Artigo recebido em 15/09/2009. Aprovado em 01/07/2010.

\begin{abstract}
The cistern is an ancient way of storing rainwater in regions lacking a source of permanent water, as the Semi-Arid Northeast of Brazil, enabling people to obtain clean water and easy to treat. This article presents preliminary considerations on survey of public policies created to solve the drought problem in the Brazilian Northeast - from the creation of the Federal Inspectorate for Works Against Drought (IFOCS) still in the Empire period, to the 1 Million Cisterns Program (P1MC) launched by president Lula in 2003. The Program is an initiative of the Articulação do Semiárido (ASA), an NGO which currently involves about 700 entities. In addition, the study also examines the influence specifically the use of cisterns in the living conditions of families in the Baixo Salitre, around the city of Juazeiro in Bahia. So, there were 34 interviews with families of this region and the results indicate how the use of cisterns positively influences the quality of life of these families, health, leisure time, income, and gender. Until 2009, were built more than 266,000 cisterns, involving 292,000 families in 6,078 municipalities.
\end{abstract}

KEYWORDS Public policy, citizenship, partnerships, Brazilian Semi-Arid region, local development. 


\section{INTRODUÇÃO}

A seca é um fenômeno natural que tem registro histórico no Nordeste brasileiro desde o ano de 1552 (VILLA, 2001). Embora tenha caráter natural e aconteça, geralmente, na mesma região, a seca ocorre em diferentes conjunturas sociais e incide, negativamente, nas condições de vida da população. Através de décadas, surgiram inúmeras ações de políticas públicas sociais na tentativa de corrigir distorções conjunturais, devido ao fenômeno das secas, entretanto nenhuma delas conseguiu resultados permanentes.

A precipitação média anual do Semiárido do Nordeste brasileiro encontra-se numa amplitude que varia de 250 a $800 \mathrm{~mm}$ anuais, distribuídos entre três e cinco meses do ano (LOPES, 2006). No município de Juazeiro (BA), a precipitação média é de 536,49 mm (Embrapa). Para suprir a deficiência de água para consumo humano no meio rural destaca-se a cisterna como uma tecnologia simples e capaz de captar e armazenar uma água limpa e indicada para o consumo humano.

Nesse sentido, o P1MC - Programa 1 Milhão de Cisternas, iniciativa de uma organização civil que se tornou uma política pública, coloca-se como o início de uma nova interação sociedadenatureza, ou seja, se o Semiárido não pode se transformar numa região úmida, pode-se mudar a forma de vida da população que nele convive, segundo ressaltam os secretários da Conferência Nacional dos Bispos do Brasil (CNBB), Dom Raimundo Damasceno Assis, e do Conselho Nacional de Igrejas Cristãs (Conic), pastor Ervino Schmidt (CÁRITAS BRASILEIRA, 2001).

Para a realização deste estudo, foi feito um levantamento bibliográfico das políticas públicas implementadas a partir do século XIX. Além de uma revisão do uso de cisternas em diversas partes do mundo, com ênfase no Semiárido do Nordeste brasileiro. A partir desses dados teóricos, foi realizado o levantamento de dados secundários e pesquisa direta, com a aplicação de um questionário junto às famílias beneficiadas com cisternas no estado da Bahia.

A escolha das comunidades foi feita a partir de informações fornecidas pela Articulação do Semiárido (ASA) - Unidade Gestora Microrregional. O critério estabelecido foi o número de cisternas, a data de término da construção e a distância da sede do município.

Para melhor avaliar os objetivos propostos pelo presente estudo, designou-se uma região com famílias beneficiadas pelas cisternas que já fizessem uso das águas captadas e armazenadas, e onde as comunidades tivessem dificuldade no acesso a outras fontes de água.

A população estudada foi constituída por 34 famílias, residentes nas comunidades de Recanto, Arame, Alfavaca, Alfavaquinha, Mulungu, Baraúna, Sobrado, Pau Preto, Pateiro e Manga, todas integrantes da bacia do Baixo Salitre, no município de Juazeiro (BA).

Os esforços de coleta de campo encontraram, na totalidade das comunidades pesquisadas, entrevistados entusiasmados e diligentes em participar das entrevistas. Todas foram realizadas nas próprias residências das famílias. No decorrer da aplicação do questionário, composto de 25 perguntas, as famílias eram interrogadas sobre as suas condições de vida antes e após a construção da cisterna. O questionário foi composto de quatro blocos: caracterização das famílias (responsável pela cisterna e número de moradores); relação com a cisterna (como a forma de abastecimento, a satisfação, duração da água de chuva captada); aspectos de melhoria de vida (saúde e renda); e características do período antes da cisterna (local onde se abastece, distância e tempo do percurso desde a casa e a qualidade da água).

O trabalho apresenta, em sua organização geral, o diálogo articulado entre o referencial teórico e os resultados da pesquisa de campo. Organiza, inicialmente, a revisão bibliográfica do tema 
desenvolvimento regional endógeno, abordando o conceito de capital social. Em seguida, elabora um levantamento das políticas públicas para a seca nordestina até hoje implantadas. Posteriormente, são apresentados os resultados da pesquisa com as famílias do Baixo Salitre, no município de Juazeiro (BA), sobre os efeitos percebidos pelas famílias frente à construção das cisternas. Por fim, são apresentadas as considerações finais e as conclusões do estudo.

\section{DESENVOLVIMENTO REGIONAL ENDÓGENO E CAPITAL SOCIAL}

As modificações ocorridas nos processos produtivos desde os anos 1980 acarretaram profundas transformações na teoria das políticas públicas de desenvolvimento regional, a partir da última década (BROSE, 2000; FISCHER, 2002; GRACIARENA, 2000; MARTINELLI E JOYAL, 2004; OLIVEIRA, 2002). Os desequilíbrios regionais preexistentes e estes advindos agora da reestruturação produtiva internacional passaram a sofrer uma análise sob diferentes ângulos, destacandose entre eles o desenvolvimento endógeno.

O desenvolvimento endógeno tem suas origens na década de 1970, quando as propostas de desenvolvimento da base para o topo surgiam com maior notoriedade. A partir daí, essa corrente evoluiu com a colaboração de novos enfoques ao problema do crescimento desequilibrado, que ficou conhecido, em suas variantes, por outras nomenclaturas, como desenvolvimento local, desenvolvimento desde baixo, desenvolvimento territorial ou mesmo desenvolvimento comunitário (ANDION, 2003; BENKO, 1999; CASTILHOS, 2002; FLEURY, 2004; FRANCO, 2002; RODRIGUES, 2005).

Já na década de 1990, a principal questão do modelo de desenvolvimento endógeno focou-se na tentativa de se entender por que o nível de crescimento variava entre as regiões e as nações, mesmo elas dispondo das mesmas condições na busca de fatores produtivos, como capital financeiro, mão de obra ou tecnologia. A solução seria encontrar, entre esses fatores, aqueles determinados dentro da região. Nesse sentido, a contribuição da teoria endogênica foi identificar que fatores de produção atualmente decisivos - como o capital social, o capital humano, o conhecimento, a pesquisa e desenvolvimento, a informação e as instituições - eram determinados dentro da região e não de forma exógena, como até então eram entendidos. Posteriormente, logo se concluiu que a região dotada desses fatores ou estrategicamente direcionada para desenvolvê-los internamente teria melhores condições de atingir um crescimento acelerado e equilibrado (SEN, 2000; ZAPATA, 2000).

Com essa evolução, o desenvolvimento regional endógeno predominante na década de 1990 pôde ser definido como um processo interno de ampliação contínua da capacidade de agregação de valor sobre a produção, bem como da capacidade de absorção da região, cujo desdobramento é a retenção do excedente econômico gerado na economia local e/ou a atração de excedentes provenientes de outras regiões. Esse processo tem como resultado a ampliação do emprego, do produto e da renda local ou da região, em um modelo de desenvolvimento regional definido (SILVEIRA; REIS, 2001; SINGER, 2002; VÁZQUEZ BARQUERO, 1988; VEIGA, 2005; WOLFE, 2000).

A capacidade de a sociedade liderar e conduzir o seu próprio desenvolvimento regional, condicionando-o à mobilização dos fatores produtivos disponíveis em sua área e ao seu potencial interno, configura a forma de desenvolvimento denominado endógeno. É possível identificar duas dimensões na endogenia do desenvolvimento regional: a primeira, econômica, na qual a sociedade empresarial local utiliza sua capacidade para organizar, da forma mais producente possível, os 
fatores produtivos da região; a segunda, sociocultural, onde os valores e as instituições locais servem de base para o desenvolvimento da região (VÁZQUEZ BARQUERO, 1988).

De forma antagônica ao pensamento normalmente associado com as teorias endogênicas, não se busca, neste enfoque, o fechamento ou o isolamento regional, nem mesmo o autocentrismo e a autossuficiência. O conceito de desenvolvimento endógeno moderno baseia-se na execução de políticas de fortalecimento e qualificação das estruturas internas, visando sempre à consolidação de um desenvolvimento originalmente local, criando as condições sociais e econômicas para a geração e a atração de novas atividades produtivas, dentro da perspectiva de uma economia aberta.

A moderna teoria regional endogênica também considera a importância da sociedade civil e das relações sociais no processo de desenvolvimento de uma região. Deve ser ressaltado que a importância da sociedade civil no processo de evolução das civilizações já havia sido analisada por estudos que remontam ao século XVIII (FERGUSON, 1998). Entretanto, o que os pesquisadores da endogenia procuram destacar é que a sociedade civil, e nela compreendidas as formas locais de solidariedade, integração social e civismo, pode ser considerada a principal agente da modernização e da transformação socioeconômica em uma região, especialmente a partir da década de 1990 (BOISIER, 1997).

A importância da sociedade civil e das relações sociais é, com a mesma ênfase, defendida por outros pesquisadores do desenvolvimento endógeno (BIRNER et al., 1995; GODARD et al., 1987; STOHR, 1990). O destaque dado aqui para a importância da sociedade civil não está inserido no debate da relação entre a sociedade e o Estado, a dicotomia entre mais ou menos Estado, ou entre a sociedade e o mercado. Trata-se da compreensão de que o desenvolvimento regional endógeno, ao considerar e dar relevância à sociedade civil regional e aos seus processos de organização social e relações cívicas, possibilita que a região atinja um crescimento equilibrado e sustentado a longo prazo.

A transformação da sociedade nesse direcionamento advém dos valores e das virtudes cívicas inerentes à sua estrutura. São esses fatores que têm a capacidade de modificar as estruturas regionais e, pelo processo cultural, transmitir para as gerações futuras as características sociais que sustentarão a evolução socioeconômica a longo prazo. O objetivo principal é combinar positivamente o civismo com a busca constante da liberdade e das oportunidades (COLEMAN, 1994; EVANS, 1995; PUTNAM, 1996;).

Nos estudos sobre o desenvolvimento regional, também podemos destacar a inserção contemporânea da concepção de "capital social". Definido como sendo o conjunto das características da organização social, que englobam as redes de relações entre indivíduos, suas normas de comportamento, laços de confiança e obrigações mútuas, o capital social, quando existente em uma região, torna possível a tomada de ações colaborativas que resultem no benefício de toda a comunidade. Em um sentido mais restrito, pode-se entender capital social como "[...] a habilidade de criar e sustentar associações voluntárias" (PORTES e NICHOLLS, 1969). O capital social é compreendido, basicamente, por sua função, sendo encontrado em organizações sociais que potencializem a produção do ser humano (COLEMAN, 1994; EVANS, 1995; PUTNAM, 1996; ABRAMOVAY, 2000; BOURDIEU, 1996, 1989; NICHOLLS, 1969; TORCAL \& MONTERO, 1998; NEJAMKIS, 1999; ROUTLEDGE \& AMSBERG, 1996; TENDLER, 2002; SANROMÀ, 1999).

Em outras palavras, o capital social, quando existente em uma região, torna possível a tomada de ações colaborativas que resultem no benefício de toda a comunidade. Enquanto o capital humano está relacionado ao indivíduo, o capital 
social tem a ver com o ambiente social propício ao desenvolvimento. Criar um ambiente (social) favorável é formar capital social. Esse capital refere-se aos laços de confiança, de compromisso, de vínculos de reciprocidade, cooperação e solidariedade, que são capazes de estimular normas, contatos sociais e iniciativas de pessoas para a potencialização do desenvolvimento humano e econômico, ou seja, os laços são muito mais resistentes que meros interesses materiais; sua força se encontra em sentimentos de fraternidade e reciprocidade (FRANCO, 2002; PASSADOR, 2006).

São observadas na literatura três vertentes sobre a relação entre Estado e capital social: As "antiestatais, as "intermediárias" e as "estatistas":

As "antiestatais" seriam aquelas cuja existência de capital social depende do desmantelamento do Estado, substituindo sua ação pelas ações da sociedade civil organizada. (CASTILHOS, 2002; ORTOLANI, 2005).

As intermediárias acreditam na organização e na articulação da sociedade como não dependentes do Estado, porém o Estado poderia funcionar como indutor de capital social. Representando essa linha está Putnam (2000), defensor de um papel mais participativo e fiscalizador dos cidadãos nos assuntos do Estado (CASTILHOS, 2002; ORTOLANI, 2005; PASSADOR 2006).

E, em oposição teórica ao primeiro grupo, os representantes da visão estatista, liderados por Evans (1995) acreditam que o Estado deve passar de mero regulador das relações sociais para a posição de ativo mobilizador social e principal indutor de capital social (CASTILHOS, 2002; NALLE, 2006; ORTOLANI, 2005; PASSADOR 2006).

A necessidade da existência de capital social para consolidar o desenvolvimento ganha visibilidade a partir dos estudos de Putnam (2000) sobre as origens do desenvolvimento da região norte da Itália. O autor identifica como motivos do melhor desempenho dessa região da Itália os elevados níveis de associativismo, de cooperação e de capacidade de formar redes e acordos de natureza diversa. O grau de confiança que existe entre os indivíduos, as normas de comportamento e os sentimentos de reciprocidade contribuem para a sensação de bem-estar geral e, portanto, para a questão do desenvolvimento. Tal percepção é que permite o estabelecimento da relação entre cidadania e desenvolvimento (PUTNAM, 2000).

Apesar de imperceptível para a grande maioria das pessoas, o capital social está presente no cotidiano de todos, em maior ou menor grau. É, assim, constituído de forças que estão acima dos interesses materiais e fazem duas ou mais pessoas se unirem em torno de um objetivo comum.

Conforme Evans (1995), os componentes que formam o capital social, entre os quais estão o engajamento cívico, a integração social e as normas de confiança, podem ser promovidos pelas esferas governamentais e, inclusive, ser utilizados com vistas ao desenvolvimento.

Por meio do capital social, a sociedade tem a capacidade de identificar suas necessidades coletivas e estabelecer conjuntamente seus objetivos. Seus integrantes não agem independentemente, cooperam na busca dos objetivos comuns, e seu comportamento nem sempre é estritamente egoísta, o que permite aos cidadãos serem protagonistas de seu próprio desenvolvimento (ABRAMOVAY, 2000).

Isso confirma a necessidade e a importância com que o capital social se apresenta nos novos conceitos de desenvolvimento local (KLIKSBERG, 1997). A capacidade de a sociedade liderar e conduzir o seu próprio desenvolvimento regional, condicionando-o à mobilização dos fatores produtivos disponíveis em sua área e ao seu potencial interno, configura o desenvolvimento denominado endógeno. Identificam-se duas dimensões nessa forma de desenvolvimento: a primeira, econômica, na qual a sociedade empresarial local utiliza sua capacidade para organizar, da melhor maneira possível, os fatores produtivos da região; 
a segunda, sociocultural, cujos valores e instituições locais servem de base para o desenvolvimento da região (PASSADOR, 2006; VASQUEZ BARQUERO, 1988).

Em resumo, o capital social se relaciona à capacidade das pessoas de uma sociedade em privilegiar os interesses do grupo em detrimento dos individuais, implementar o trabalho conjunto com o objetivo de alcançar metas comuns, organizar-se e associar-se, compartilhar valores, normas e gestão das organizações comunitárias. Tais características denotam uma série de relações estáveis e duradouras estabelecidas entre as pessoas e os diversos grupos formados dentro do território, podendo ser consideradas como o principal agente de modernização e transformação socioeconômica em uma região, propiciando um nível ótimo de desenvolvimento social para a comunidade (FRANCO, 2002).

Dentro desse conceito, o aspecto da confiança é visto como o facilitador da vida social ao gerar e potencializar os recursos econômicos. Dessa forma, a confiança é alcançada a partir do conhecimento mútuo entre os membros da comunidade e da tradição de ação comunitária.

Para Coleman (1994), existe uma complementação entre capital físico-econômico (insumos, infraestrutura e financiamento), capital humano (educação e preparação técnica) e capital social (relações de confiança). A otimização do capital físico-econômico e do capital humano é atingida na medida em que as relações de confiança e reciprocidade aumentam na comunidade.

Temos, ainda, a visão de Melo Neto e Fróes (1999) sobre capital social, que o define pelo acúmulo de experiências participativas e organizacionais ocorridas na base de uma comunidade e que reforçam os laços entre as pessoas, grupos e instituições; sendo necessária a existência de seis fatores na base para a construção do capital social: participação social, organização, solidariedade social, iniciativa, cooperação e confiança.
Dentro dessa amplitude, o conceito de capital social integra aspectos inter-relacionados, como: a reciprocidade, redes sociais, desenvolvimento social, cooperação e governabilidade (ABU-ELHAJ, 1999; PASSADOR \& CUNHA, 2008).

Nesse contexto, o desenvolvimento regional endógeno e o capital social apontam para construção de um novo sujeito coletivo do desenvolvimento; ou de um novo padrão de políticas, baseado na parceria entre as diversas instâncias e os órgãos do poder público, as empresas privadas e as organizações da sociedade civil. Esse processo pode ser transformador na relação entre Estado e sociedade, e pode vir a representar mudanças significativas em nossa matriz política, econômica e social, especificamente nas políticas públicas de combate à seca, como o P1MC, que veremos adiante.

\section{POLÍTICAS PÚBLICAS CONTRA OS EFEITOS DA SECA NO NORDESTE BRASILEIRO}

A intervenção do Estado no Nordeste foi sempre marcada pela centralização e fragmentação das ações, e se concretizava com a criação de órgãos nacionais para o combate à seca, os quais se transformavam em objeto de disputas políticas entre os diversos segmentos da elite rural. A ação desenvolvida por esses órgãos limitava-se à construção de grandes açudes públicos, perenizando grandes extensões de rios, sobretudo a construção de milhares de pequenos e médios açudes dentro de propriedades privadas, de forma a assegurar água para a produção agropecuária e o funcionamento de agroindústrias.

As primeiras iniciativas para lidar com a questão da seca foram direcionadas a oferecer água à zona do Semiárido. Nessa ótica, foi criada a de Obras Contra as Secas (Decreto $n^{\circ}$ 7.619, de 21 
de outubro de 1909), atual Departamento Nacional de Obras Contra a Seca (DNOCS), com a finalidade de centralizar e unificar a direção dos serviços, visando à execução de um plano de combate aos efeitos das irregularidades climáticas. Foram iniciadas as construções de estradas, barragens, açudes, poços, como forma de proporcionar apoio para que a agricultura suportasse os períodos de seca.

A ideia de resolver o problema da água no Semiárido foi, basicamente, a diretriz traçada pelo governo federal para o Nordeste e prevaleceu, pelo menos, até meados de 1945. Na época em que a Constituição brasileira de 1946 estabeleceu a reserva no orçamento do governo de 3\% da arrecadação fiscal para gastos na região nordestina, nascia nova postura, distinta da solução hidráulica na política antisseca. Abandonou-se, na época, a ênfase em obras em função do aproveitamento mais racional dos recursos, conforme podemos observar no histórico dos programas do governo descritos a seguir.

Assim, é possível apresentar, de maneira resumida, a cronologia dos programas de intervenção, bem como as instituições envolvidas nas políticas de combate à seca no Brasil (NASCIMENTO, 2005). São três, os períodos:

Assim, é possível apresentar, de maneira resumida, a cronologia dos programas de intervenção, bem como as instituições envolvidas nas políticas de combate à seca no Brasil (NASCIMENTO, 2005). São três, os períodos:

\section{Medidas de salvação}

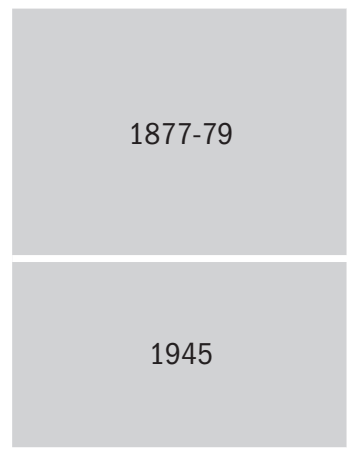

0 Império instituiu uma Comissão Imperial para estudar a abertura de um canal que comunicasse as águas do rio Jaguaribe com as do rio São Francisco, porém não foi concretizado, e a prioridade foi dada à construção de açudes e poços tubulares. Em 1904, foram criadas várias comissões: Açudes e Irrigação, Estudos e Obras contra os Efeitos das Secas e de Perfuração de Poços. Em 1909, foi instituída a Inspetoria de Obras Contra as Secas (IOCS), a qual foi transformada em 1919 em Inspetoria Federal de Obras Contra as Secas (IFOCS).

A IFOCS foi renomeada Departamento Nacional de Obras Contra a Seca (DNOCS). Em 1948, foi criada a Comissão do Vale do São Francisco, concebida para criar um novo método de gestão de combate às estiagens.

Desenvolvimento planejado

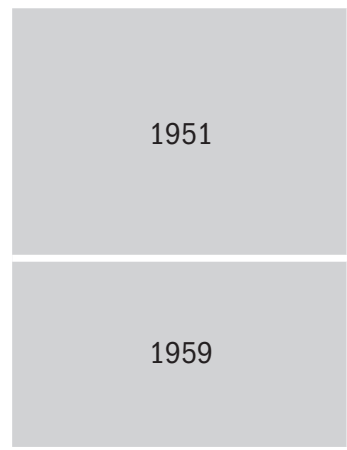

0 Banco de Nordeste foi criado em 1952 para apoiar financeiramente os municípios que faziam parte do Polígono das Secas. Em 1956, foi criado o Grupo de Trabalho para o Desenvolvimento do Nordeste (GTDN) com 0 intuito de realizar estudos socioeconômicos para o desenvolvimento do Nordeste.

Nesse ano foi criado o Conselho de Desenvolvimento do Nordeste (Codeno), tendo Celso Furtado como diretor e encarregado de lutar pela aprovação da Superintendência do Desenvolvimento do Nordeste (Sudene) no Congresso Nacional. Nesse ano a Sudene foi instituída. 

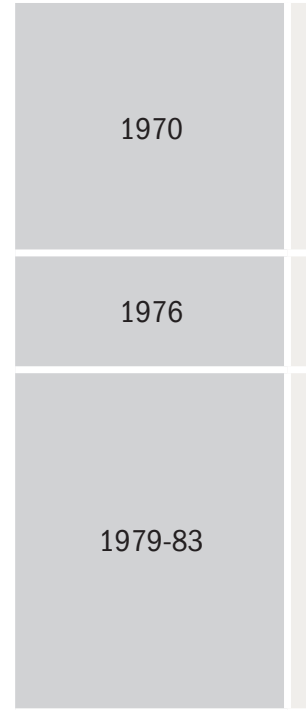

1987

1990-93

1998

2001-06
Os programas de desenvolvimento regional passaram a impulsionar a agricultura irrigada no país. Os principais foram: Programa de Integração Nacional (PIN), o Programa de Redistribuição de Terra e de Estímulo à Agroindústria do Norte e Nordeste (Proterra, 1971), incorporados ao I Plano de Desenvolvimento Nacional (I PND) e o Programa Especial para 0 Vale do São Francisco (Provale, 1972) e Programa de Desenvolvimento de Áreas Integradas do Nordeste (Polonordeste, 1974), incorporados ao II Plano Nacional de Desenvolvimento (II PND).

Foi criado o Projeto Sertanejo, que visava tornar a economia mais resistente aos efeitos da seca pela associação entre agricultura irrigada e seca.

Em 1979, foi implementado o Programa de Recursos Hídricos do Nordeste (Prohidro), através de acordo de cooperação com o Banco Mundial, para aumentar a oferta de recursos hídricos por meio da construção de açudes públicos e privados e perfuração de poços. Mais tarde o programa foi renomeado Proágua. Em 1978, foi criada a Política Nacional de Irrigação, que enfatizava a função social da irrigação, destacando, no caso nordestino, 0 combate à pobreza e a resistência à seca. Em 1981, foi criado o Programa Provárzeas, a cargo da Emater, para prestar assistência ao pequeno agricultor. Em 1984, houve um acordo entre o Ministério da Integração (MI) e o Banco Internacional para Reconstrução e Desenvolvimento (BIRD) para admitir a implantação de médias empresas nos projetos de irrigação, que podiam ocupar até $50 \%$ dos perímetros.

0 Programa de Irrigação do Nordeste (PROINE, 1986) foi ampliado para Programa Nacional de Irrigação (PRONI, 1986). 0 Projeto Nordeste I englobou seis programas, dos quais vingou apenas o Programa de Apoio ao Pequeno Produtor Rural (PAPP) do Semiárido.

0 Instituto de Pesquisa Econômica Aplicada (Ipea) divulgou o Mapa da Fome no Brasil (1993). Devido à pressão popular (Movimento Ação da Cidadania contra a Fome, Miséria e pela Vida), foi criado o Conselho Nacional de Segurança Alimentar (Consea), que coordenou o Programa de Distribuição Emergencial de Alimentos (Prodea, 1993). Esse programa originou o programa Bolsa Renda em 2001 e o Bolsa Família em 2004. Nos anos 1990, iniciaramse os debates sobre os projetos de assentamento de pequenos produtores versus a participação do produtor empresário. Em 1997, foi constituído o modelo de irrigação, com lotes familiares para projetos de assentamento e projetos públicos de irrigação totalmente ocupados por empresas.

Criação do Programa Federal de Combate aos Efeitos da Seca, coordenado pela Sudene, para ajudar os atingidos pela seca. Em 1998, o Tribunal de Contas da União (TCU) passou a publicar os resultados das auditorias de programas sociais. Dentre outros, foram auditados o Programa Nordeste I (DNOCS e a Companhia de Desenvolvimento dos Vales do São Francisco e Parnaíba (Codevasf), Proágua (DNOCS e Sudene) e o Programa de Dessalinização Água Boa. Para evitar a desarticulação dos projetos públicos de irrigação, em dezembro de 1999 a Sudene, a Superintendência da Amazônia (Sudam), o DNOCS e a Codevasf foram vinculados ao Ministério da Integração (criado em setembro de 1999). Em julho de 1999, foi elaborado pelo Conselho Nacional de Defesa Civil (Condec) o Manual para Decretação de Situação de Emergência ou de Estado de Calamidade Pública.

Criação do Programa 1 Milhão de Cisternas Rurais P1MC, dentro do Programa de Formação e Mobilização Social para a Convivência com o Semiárido, da ONG Articulação do Semiárido (Asa), criada em 1999. 0 P1MC passa a ser política pública do governo federal, ao ser firmado o Termo de Parceria $n^{0}$ 001/2003 com o Ministério do Desenvolvimento Social (MDS). Devido às denúncias de corrupção divulgadas pelo TCU, a Sudene foi extinta em maio de 2001, tendo sido renomeada Agência de Desenvolvimento do Nordeste (Adene) em junho de 2004.
Observando a trajetória acima, é possível verificar que os três períodos das políticas públicas de combate à seca, organizados assim por conveniência de análise, apresentam características distintas. No primeiro período (do ano de 1877 até os anos 40 do século XX), a atuação do Estado dava-se através das "medidas de salvação", ou seja, distribuição de alimentos entre os retirantes 
que conseguiam chegar às capitais, e de esmolas aos que permaneciam no interior. No aspecto técnico, investia-se em infraestrutura hidráulica, como: construção de várias e grandiosas obras de açudagem, poços profundos e barragens.

Num segundo período (do final da década de 1950 até a década de 1970), a atenção política antisseca migrou das obras de açudagem para o aproveitamento racional dos recursos hídricos. Nesse contexto, foram criadas pelo governo federal, em 1948, a Comissão do Vale do São Francisco, seguidamente pelas instituições Banco do Nordeste do Brasil (BNB) e Superintendência do Desenvolvimento do Nordeste (Sudene). Em 1956, o governo federal, instituiu o Grupo de Trabalho para o Desenvolvimento do Nordeste (GTDN), cuja importância consistiu na identificação das disparidades regionais. De acordo com o GTDN, foram precisas medidas amplas e uma soma de investimentos muito maior para o desenvolvimento da região. Essa fase foi intitulada desenvolvimento planejado, quando as políticas antisseca procuraram se embasar em análises mais cuidadosas da realidade.

O terceiro período, que se inicia a partir de 1970, foi marcado pela implantação de vários programas, tais como: Proterra (1971), Provale (1972), Polonordeste (1974), Projeto Sertanejo (1976) e Prohidro (1979).

Apesar das inúmeras políticas públicas implementadas ao longo da história do Nordeste semiárido, o que se observa é que elas se revelaram incompletas e desintegradas, pois a cada governo interromperam-se ou alteraram-se os projetos do governo anterior.

Segundo Villa (2001), o semiárido precisa de uma intervenção do governo federal que se contraponha ao suposto descaso das "elites regionais". Para ele, sempre faltaram ações planejadas. Para ilustrar sua afirmação, o historiador compara o fenômeno da estiagem ao tsunami, e diz que o problema da seca é pior, pois pode ser previsto com bastante antecedência. Segundo o autor, a responsabilidade das autoridades federais e das elites políticas nordestinas é ainda maior, porque todos acabam sendo cúmplices de uma tragédia anunciada (VILLA, 2001). Em outras palavras, historicamente, nessa região, a distribuição de água permeia os interesses das elites econômicas locais ao vincularem o aceso à água ao apoio político em períodos eleitorais.

Nesse contexto, desde o primeiro mandato do atual governo do presidente Lula da Silva, buscou-se incentivar e fortalecer as iniciativas da sociedade civil com o objetivo de agir de maneira mais eficaz no combate à seca. Dessa forma, a partir de 2003, vêm sendo sistematicamente organizados aparatos institucionais e destinados recursos da União para a construção de cisternas. Merecem destaque, nessa política, como se verá em detalhes mais adiante, o Programa 1 Milhão de Cisternas Rurais (P1MC) e a organização não governamental Articulação do Semiárido (ASA), sua principal gestora.

\section{O PROGRAMA 1 MILHÃO DE CISTERNAS (P1MC)}

Segundo Gnadlinger (2000), a coleta e o aproveitamento da água de chuva tem sido uma técnica bastante popular em muitas partes do mundo, especialmente em regiões áridas e semiáridas (aproximadamente 30\% da superfície da terra). A coleta de água da chuva foi inventada independentemente em diversas partes do mundo e em diferentes continentes há milhares de anos. Ela foi usada e difundida especialmente em regiões semiáridas, onde as chuvas ocorrem somente durante poucos meses e em locais diferentes.

A captação de águas de chuva em sistemas individuais de abastecimento de água tem sido uma prática usual há muitos anos. Segundo Plínio To- 
maz (2003), existem reservatórios escavados desde 3600 a.C. Na Pedra Moabita (datada de 850 a.C.), uma das inscrições mais antigas do mundo encontradas no Oriente Médio, o rei Mesha, dos moabitas sugere que as casas tenham captação de água da chuva. Na China, essa técnica já era conhecida no planalto de Loess, há 2 mil anos, quando já existiam cacimbas e tanques para a água da chuva (GNADLINGER, 2000).

Na década de 1970, várias cidades da Índia tiveram nas técnicas de captação de água de chuva a solução para a sua produção agrícola e passaram da situação de importadoras a exportadoras de alimentos. Em meados da década de 1980, a população da cidade de Gopalpura, também na Índia, localizada em uma região propensa às secas, passou a reviver as práticas de captação de escoamento superficial. O sucesso do empreendimento motivou outras 650 cidades próximas a desenvolver esforços similares, levando à elevação do nível do lençol freático, rendimentos maiores e mais estáveis provenientes das atividades agrícolas e redução das taxas de migração. Impressionado com o sucesso da experiência do uso de técnicas de captação de águas de chuva, o ministro-chefe do estado indiano de Madhya Pradesh repetiu a iniciativa em 7.827 cidades. O projeto atendia a quase 3,4 milhões de hectares de terra entre 1995 e 1998 (WORLD WATER COUNCIL, 2000, apud PALMIER, 2001).

No mundo árabe, sistemas de captação de água de chuva sempre foram utilizados e desenvolvidos nessa região do planeta, que, historicamente, enfrenta crônica escassez de água. As técnicas de captação de água de chuva são praticadas há milênios em vários países da referida região, sendo comuns em países como a Arábia Saudita, Catar, Emirados Árabes Unidos, Iêmen, Omã e Tunísia. Nesses países utiliza-se o sistema de recarga de águas subterrâneas através da construção de barragens que fazem parte de planos nacionais de desenvolvimento (PETRY e BOERIU, 1998, apud
PALMIER, 2001).

Nas Américas, Gnadlinger (2000) salienta as práticas pré-colombianas do povo maia na península de Yucatán, hoje México. O México como um todo é rico em antigas e tradicionais tecnologias de coleta de água da chuva, datadas da época dos astecas e maias. Ao sul da cidade de Oxkutzcab, ao pé do monte Puuc, ainda hoje podem ser vistas as realizações do povo maia. No século X já existia uma agricultura baseada no aproveitamento da água de chuva. As pessoas viviam nas encostas das montanhas e sua água potável era fornecida por cisternas com capacidade de 20 mil a 45 mil litros, chamadas chultuns.

Como se pode perceber, a captação de água de chuva tem se tornado uma medida estratégica para o desenvolvimento social e econômico das regiões semiáridas do mundo inteiro.

No Semiárido Nordestino, armazenar e usar a água das chuvas adequadamente também é um desafio, uma vez que esse terreno se caracteriza por solos rasos e com baixa capacidade de retenção de água subterrânea.

A pluviosidade nordestina é irregular e diferenciada. A água do subsolo é quase sempre salobra. A grande maioria do solo não oferece condições para a perfuração de poços profundos. Existem poucos rios; na realidade, existem apenas duas grandes bacias: a do São Francisco e a do Parnaíba. Nessas circunstâncias, tornam-se imprescindíveis a busca de soluções alternativas e a criação de uma nova mentalidade, uma nova cultura e adaptação ao meio ambiente semiárido.

A construção de cisternas acompanhada por um processo educativo de gerenciamento de uso da água captada tem se mostrado eficiente no combate à seca nordestina. Os estudos especializados na área de consumo humano e qualidade de vida coincidem e estimam que, em média, as necessidades aceitáveis de água para beber, cozinhar e fazer a higiene bucal (típicas dos assistidos pelos programas de cisternas) são da ordem 
de 14 litros/pessoa/dia ou 16 mil litros/família/8 meses. No semiárido nordestino, os índices pluviométricos históricos são suficientes para atender às necessidades técnicas de implantação com sucesso de projetos dessa natureza. A título de exemplo, dados estatísticos sistemáticos colhidos em Iguaraci, município com menor índice pluviométrico da região do Pajeú, sertão pernambucano $(344,6 \mathrm{~mm}$, um dos menores do Nordeste), mostram que foi possível conseguir uma captação mínima de 24 mil litros de água por residência ao ano utilizando telhados com $78 \mathrm{~m}^{2}$, subtraindo perdas de $10 \%$.

Desde a década de 1970, a Embrapa faz experiências com cisternas, obtendo excelentes resultados, mas aquelas experiências bem-sucedidas não foram disseminadas para a população por falta de uma política institucionalizada, particularmente voltada para a população rural do Semiárido Brasileiro (GNADLINGER, 2000).

Na década de 1990 foi criado o Instituto Regional da Pequena Agropecuária Apropriada (Irpaa), entidade não governamental sem fins lucrativos, sediada no município de Juazeiro/Bahia, que desde a sua criação desenvolve trabalho técnico na busca de cisternas mais resistentes. São elas: cisternas de placa, tijolos e cal, tela de cimento e alambrado. Também vem desenvolvendo sistemas de construção de cisternas em consórcio com outras organizações não governamentais, organizações sócias de base e comunidades locais organizadas. No decorrer desses trabalhos, percebeu a necessidade de implementar programas educacionais estruturados para incentivar a convivência com o clima semiárido e um manejo adequado da água. Nos anos seguintes, a Embrapa e o Irpaa organizaram vários Simpósios Brasileiros de Captação de Água de Chuva, através dos quais deram um grande impulso à utilização da água de chuva.

Em julho de 1999, durante a $3^{a}$ Conferência das Partes da Convenção de Combate à Deserti- ficação e à Seca (COP3), em Recife, foi criada a Articulação do Semiárido (ASA) - entidade não governamental que atualmente já congrega cerca de 700 entidades. Na ocasião, a sociedade civil organizada e atuante na região do Semiárido Brasileiro, reproduzindo a experiência da Conferência Rio-92, e promoveu o Fórum Paralelo da Sociedade Civil. A ASA teve um papel decisivo na coordenação desse processo, vindo a consolidar-se como espaço de articulação política da sociedade civil em fevereiro de 2000. A base de sua constituição é a Declaração do Semiárido, documento que sintetiza as percepções dos grupos participantes da ASA em torno da região. A partir dessas experiências e da ação protagonista da ASA é que se propôs e se desenvolveu o Programa 1 Milhão de Cisternas (P1MC).

O Programa de Formação e Mobilização Social para a Convivência com o Semiárido: 1 Milhão de Cisternas Rurais (P1MC) iniciou-se no ano de 2001, através de um Projeto Piloto financiado pelo Ministério do Meio Ambiente (MMA), para a construção de 500 cisternas e elaboração do projeto, mobilização nos estados, seminários e oficinas (PEREIRA, 2006).

A característica principal da proposta é divulgar um modelo de gestão que seja assumido integralmente pela mesma comunidade de interesse e beneficiária da política, organizada como sociedade civil, que contribui ativamente na elaboração da referida política e cria, utiliza e aperfeiçoa sistemas de controle social rigorosos nos diferentes níveis de implementação das ações programáticas.

$\mathrm{O}$ PIMC estabelece junto às comunidades rurais do Semiárido Brasileiro, um processo de capacitação que pretende envolver ao final, diretamente, 1 milhão de famílias. Nesse processo é abordada a questão da convivência com o Semiárido, com enfoque específico no gerenciamento de recursos hídricos, construção de cisternas, gerenciamento de recursos públicos e administração financeira dos recursos advindos do P1MC. 
A cisterna é o passo inicial para que as famílias possam perceber que é possível conviver com e se desenvolver no Semiárido.

A cisterna de placa, modelo adotado pelo P1MC, é uma tecnologia simples e barata. Um reservatório de água com formato redondo construído ao pé da casa, meio encravado no chão (2/3), meio fora, que capta a água de chuva do telhado das casas. O projeto prevê um curso de gerenciamento de recursos hídricos com as famílias beneficiadas para que aprendam a gerenciar de forma racional a sua água de beber e cozinhar, para que dure por todo o longo período de secas (entre 8 e 10 meses). As cisternas são vedadas, não permitindo a entrada de luz e insetos. Sem luz, não há procriação de algas. Na entrada da água, há um filtro, que impede a passagem de impurezas. A cisterna utiliza as águas de chuvas captadas pelo telhado da casa e canalizadas por calhas ou bicas. A água conserva-se limpa e apropriada ao consumo humano.

O custo de uma cisterna, com todos os componentes, gira em torno de $\mathrm{R} \$ 1.800,00$ (um mil e oitocentos reais). Sendo que cerca de $\mathrm{R} \$ 350,00$ (trezentos e cinquenta reais) constitui a contrapartida das famílias, ou seja, a escavação do buraco, a areia quando essa está disponível nas proximidades da casa, alimentação e hospedagem dos pedreiros. Assim, o valor da construção propriamente dita é de aproximadamente $\mathrm{R} \$ 1.450,00$ (mil quatrocentos e cinquenta reais), ou seja, 80\% do custo total (PEREIRA, 2006).

A construção de uma cisterna leva em média 5 (cinco) dias, e na grande maioria das vezes conta com a ajuda da própria família e de vizinhos, no sistema de mutirão. A capacidade da cisterna é de 16 mil litros de água potável - a água de chuva na zona rural do Semiárido Nordestino, onde a poluição atmosférica como é conhecida nos grandes centros urbanos é praticamente inexistente, apresenta-se como uma das mais limpas da natureza.

O volume armazenado é suficiente para abas- tecer uma família de até cinco pessoas durante o período de seca, com um consumo diário de 14 litros/pessoa. Para a saturação do reservatório, com capacidade para 16 mil litros, são necessários $500 \mathrm{~mm}$ de chuva em uma área de coleta (telhado) com um mínimo de $40 \mathrm{~m}^{2}$.

Se construídas seguindo os padrões técnicos e utilizando material de boa qualidade, as cisternas devem ter durabilidade mínima de 40 anos. Os problemas apresentados são decorrentes de: uso de material de má qualidade; técnicas inadequadas de construção; não adequação de uso do material ao tipo de solo; falta de cuidados especiais de manutenção, tais como não deixar a cisterna vazia ou não construí-las próximas a árvores.

As cisternas caseiras têm apresentado a tecnologia mais viável para a convivência com o Semiárido. Conforme Poletto (2001), as cisternas reúnem uma série de vantagens que lhes conferem essa classificação: baixo custo, facilidade de disseminação da tecnologia entre os meios populares menos alfabetizados ou analfabetos, e possibilidade de ser articulada com a reeducação da família quanto ao cuidado necessário para a preservação da qualidade da água.

A influência das cisternas na saúde das famílias (principalmente idosos e crianças) é imediata. Facilita também o trabalho das mulheres, tantas vezes alquebradas pela labuta de buscar água em fontes (barreiros, aguadas, poços etc.) na maioria das vezes bastante distantes. Ocorre também uma relativa libertação destas comunidades carentes em relação aos donos dos açudes e aos carrospipas, de proprietários privados ou pertencentes às pequenas Prefeituras. Em quaisquer modalidades, todavia e invariavelmente, o acesso à água potável sempre esteve sob o controle das classes dirigentes locais e de seus interesses políticos, acostumados a domesticar a população pela sede (VILLA, 2001).

Atingir 1 milhão de famílias em cinco anos era a meta do projeto. Apesar de não chegar a 1 
milhão, este continua sendo o maior projeto de abastecimento de água para consumo humano destinado à população do Semiárido existente até hoje no Brasil. É a possibilidade de se armazenar algo em torno de 16 bilhões de litros.

O PlMC não pretende ser apenas um programa de transferência de ativos e distribuição de renda, mas também promover mudança cultural e fortalecimento do capital social. Por ter uma abordagem universalista e não baseada em reivindicações corporativas, propõe um padrão de relacionamento entre Estado e a sociedade sobre questões relacionadas às infraestruturas e aos serviços públicos. Visa assim o fortalecimento institucional das organizações de base, para o fortalecimento e desenvolvimento de alternativas locais e a gestão dos recursos públicos.

Foi somente após perceber os sensíveis impactos benéficos da construção de cisternas (pilotos) em algumas comunidades que a ASA tomou a decisão de ampliar o projeto, associando-se às políticas governamentais. Um convênio celebrado com o Ministério do Meio Ambiente (MMA), cujo objeto era a construção de 500 cisternas, permitiu que a ASA realizasse experimentos para o processo de mobilização e sensibilização de comunidades e instituições governamentais e não governamentais. Posteriormente foi celebrado um convênio com a Agência Nacional das Águas (ANA) para a construção de 12.400 cisternas.

No ano de 2003 foi firmado o Termo de Parceria no 001/2003 com o Ministério do Desenvolvimento Social (MDS) e a Associação Programa 1 Milhão de Cisternas para o Semiárido (AP1MC). Dessa forma, o Programa toma feições de política pública, com orçamento definido.

Atualmente, o Programa vem recebendo apoio e firmando parcerias também com instituições privadas. Em todo o Semiárido Nordestino, existem diversos exemplos da participação da iniciativa privada, tanto nacional como internacional, tais como: Federação Brasileira dos Bancos (Febraban); Sindicato dos Metalúrgicos do ABC; Adote, iniciativa da microrregião de Juazeiro (BA); cooperativas italianas (COSPE, Ucodep e Forlimpopolli); e doações de pessoas físicas da Holanda.

Até 2009, foram construídas mais de 266 mil cisternas, mobilizando 292 mil famílias, em 6.078 municípios. Também foram capacitadas 268 mil famílias em recursos hídricos, além de 5.500 pedreiros na região.

Tabela 1 - Comparativo: cisternas, poços e aguadas

\begin{tabular}{|l|l|l|l|l|l|l}
\hline & \multicolumn{2}{|c|}{ CISTERNAS x POÇOS x AGUADAS } \\
\hline & Cisternas & Poços & $\begin{array}{l}\text { Aguadas (fonte, rio, lagoa ou qualquer } \\
\text { manancial existente numa propriedade) }\end{array}$ \\
\hline Quanto à localização & Perto & Distantes & Distantes \\
\hline Quanto ao custo & Baixo & Médio & Médio \\
\hline Manutenção & Fácil e barata & Especializada e cara & Fácil e barata \\
\hline Qualidade da água & Boa & Ruim (salobra) & Ruim \\
\hline Quanto ao solo & Independe do tipo de solo & $\begin{array}{l}\text { 0 solo do semiárido é predominan- } \\
\text { temente cristalino, necessitando de } \\
\text { perfurações profundas (até } 60 \text { m) }\end{array}$ & Existem limitações de solo \\
\hline Evaporação & Inexpressiva & Alta \\
\hline
\end{tabular}




\section{RESULTADOS OBTIDOS}

Das 34 famílias entrevistadas, 23 (68\%) possuem mulheres como responsáveis pela cisterna. Vale destacar que ser o responsável significa, neste caso, cuidar da manutenção física dos equipamentos (obra civil, bomba de gude, telhado e ca- lhas de coleta etc.) e do uso do estoque de água para os fins que ela é mais necessária (beber, cozinhar e realizar higiene bucal). É o responsável quem também decide se e o quanto vai fornecer de água da sua cisterna às famílias de vizinhos não beneficiados pelo programa.

\section{Gráfico 1 - Responsável pela cisterna}

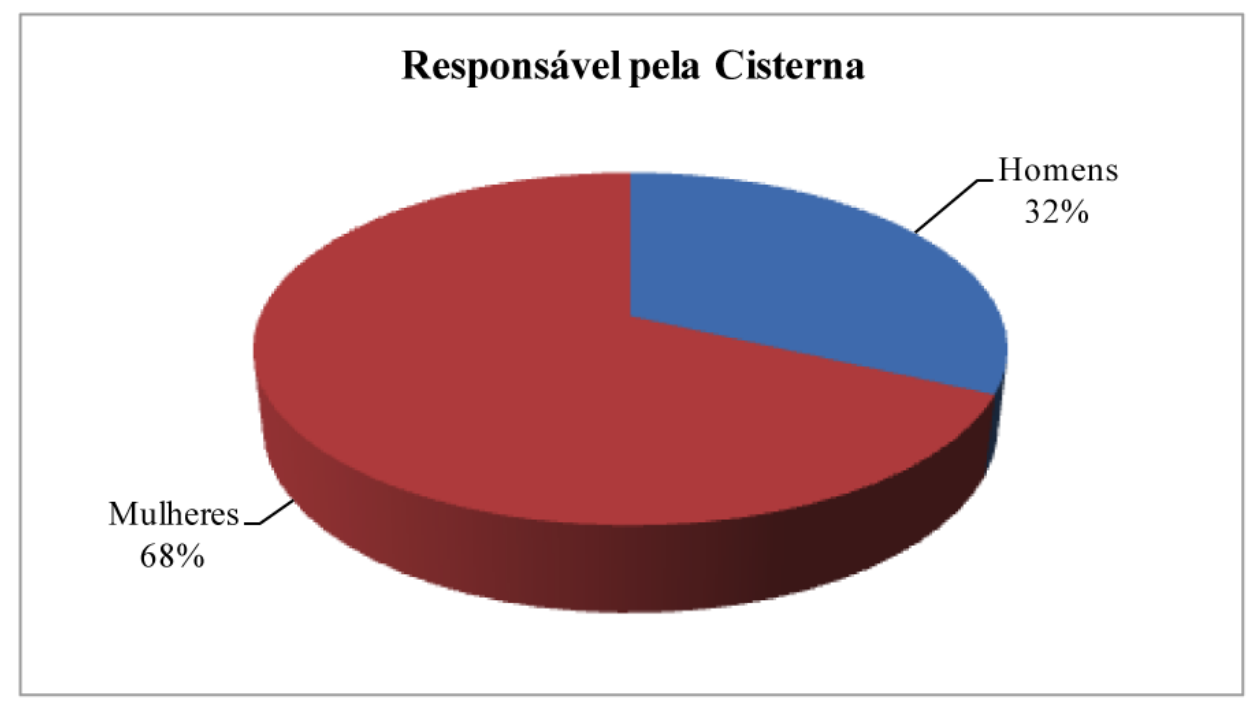

É preciso levar em conta que, na região, é prática comum os homens se deslocarem, como acontece com frequência em muitas outras regiões rurais do interior nordestino, para atividades agrícolas remuneradas nas safras do Sudeste do país. É o caso típico da colheita da cana-de-açúcar no estado de São Paulo, quando os homens passam às suas esposas a responsabilidade de chefiar as casas durante os meses do corte. Além disso, a mulher parece ser mais apta para a manutenção da vida dos seus familiares, bem como apresenta um sentimento mais apurado de solidariedade junto à comunidade da qual faz parte.

Como, em outras experiências de políticas públicas (renda mínima; mutirões habitacionais; cooperativas de artesanato; arranjos produtivos locais etc.) que envolvem ações articuladas e consórcios comunitários, a participação feminina merece destaque. Parece não ser diferente, aliás, nesses programas e políticas públicas do Semiárido do Nordeste e dirigidos à gestão sustentável dos recursos hídricos, fonte de vida por excelência.

As cisternas com capacidade de 16 mil litros são as mais adequadas para a realidade da região, pois $76 \%$ das famílias têm entre 1 e 5 moradores, que consomem 3.360 e 16.800 litros, respectivamente, de água durante um período de 8 meses (240 dias), com um consumo diário de 14 litros/ pessoa. Dessa forma, essas famílias terão condi- 
ções de captar e armazenar água suficiente para passar o período de estiagem (8 meses), com água disponível para beber, cozinhar e realizar a higiene bucal. Porém, é importante salientar que, se somente uma família não conseguir armazenar a quantidade de água ideal para passar o período de estiagem, já é suficientemente aconselhável que o dimensionamento das cisternas seja repensado, saindo da forma padronizada para uma escala de tamanho variável com o número de moradores.

\section{Gráfico 2 - Número de moradores / domicílio}

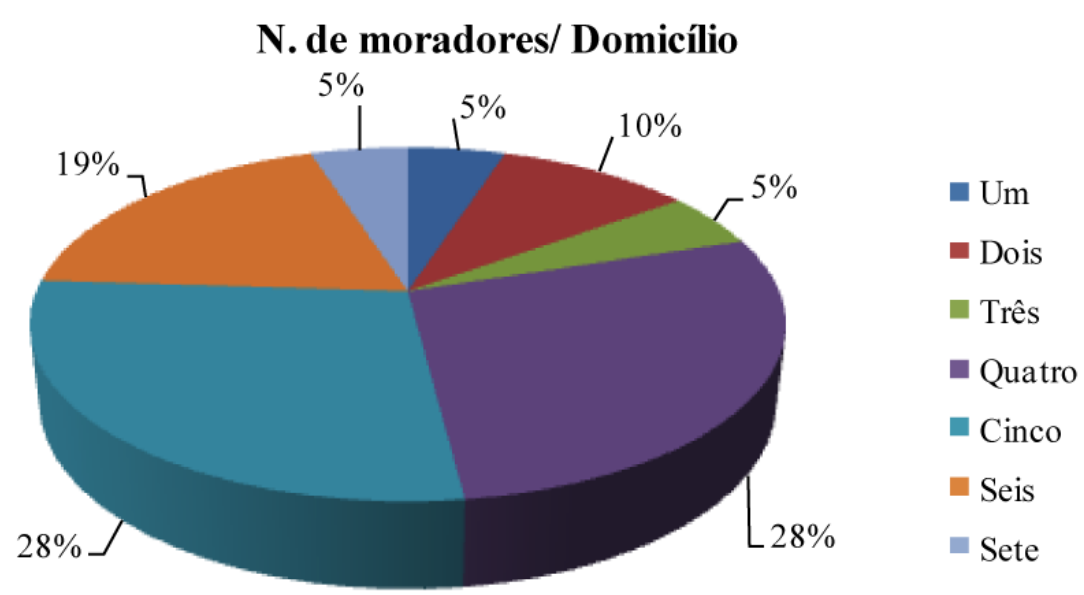

Dos entrevistados, 90\% declararam que usam a água da cisterna somente para beber, cozinhar e escovar os dentes.

\section{Gráfico 3 - Uso da água}

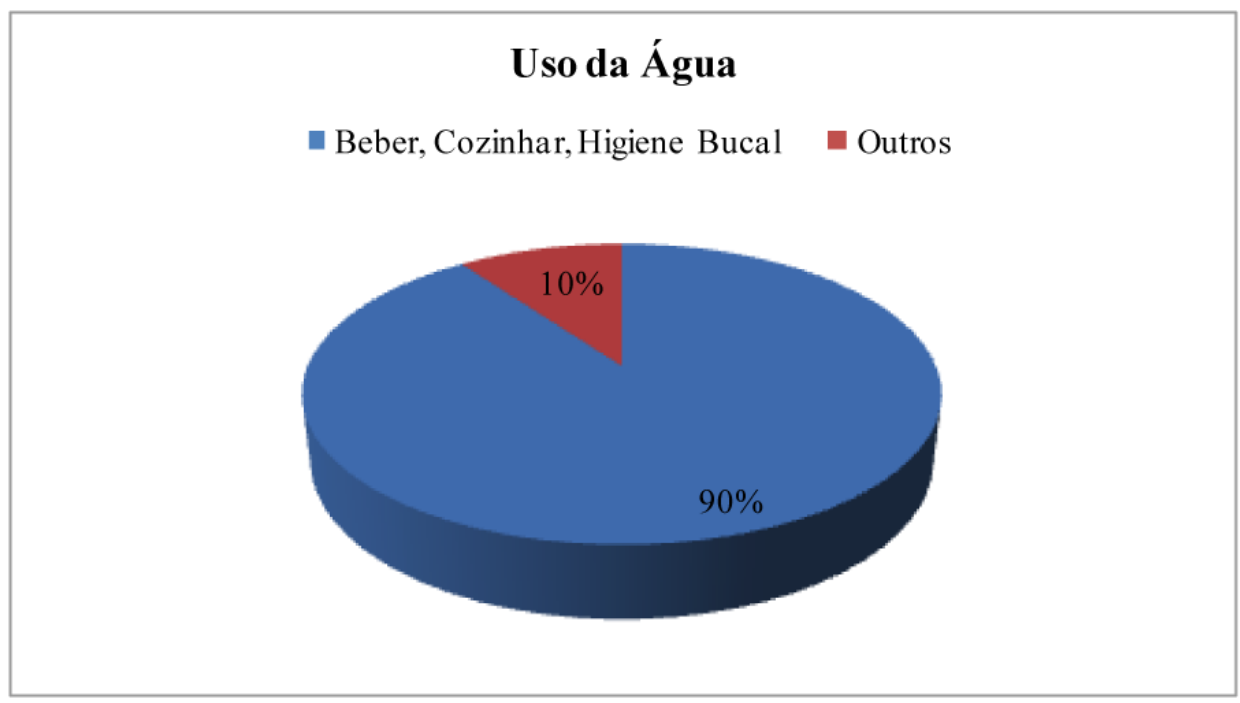


Das 34 famílias entrevistadas, 95\% tiveram participação na construção das cisternas. Isso demonstra que a participação dos atores sociais é um dos pontos fortes do Programa 1 Milhão de Cisternas (P1MC). É o que o diferencia das políticas públicas usuais de combate à seca.

A cisterna não é feita apenas para a família. Ela também é feita pela família, o que produz um sentimento de propriedade que ultrapassa o sentido de posse e uso. Apropriada em sua tecnologia de construção e operação, se torna uma extensão da vida e das decisões da coletividade, isto é, familiar e comunitária.

\section{Gráfico 4 -}

\section{Participação na} construção da cisterna

\section{Participou da Construção da Cisterna}

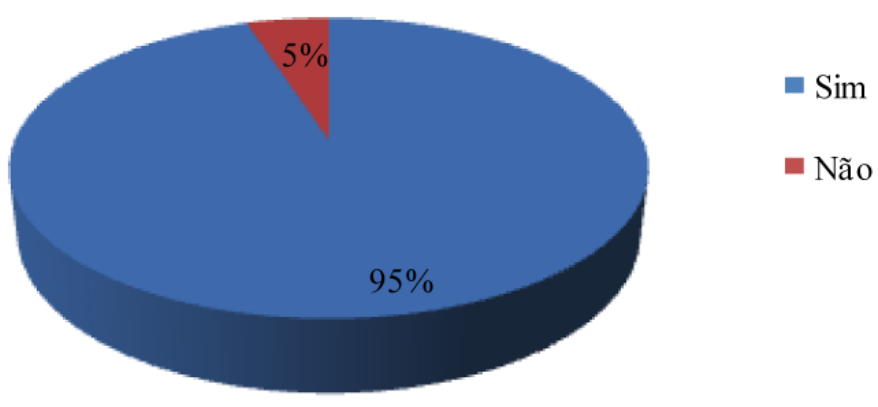

Das 34 famílias entrevistadas, apenas 25\% afirmaram que só abasteceram as cisternas com água da chuva, os outros 75\% já tinham abastecido com o carro-pipa. Segundo os entrevistados, o abastecimento com o carro-pipa só aconteceu porque eles forneceram a água da chuva coletada na cisterna para as famílias vizinhas que ainda não foram beneficiadas pelo P1MC. Acredita-se que, com ampliação e continuidade do programa, esse problema não persistirá.
Gráfico 5 -

Participação na construção da cisterna

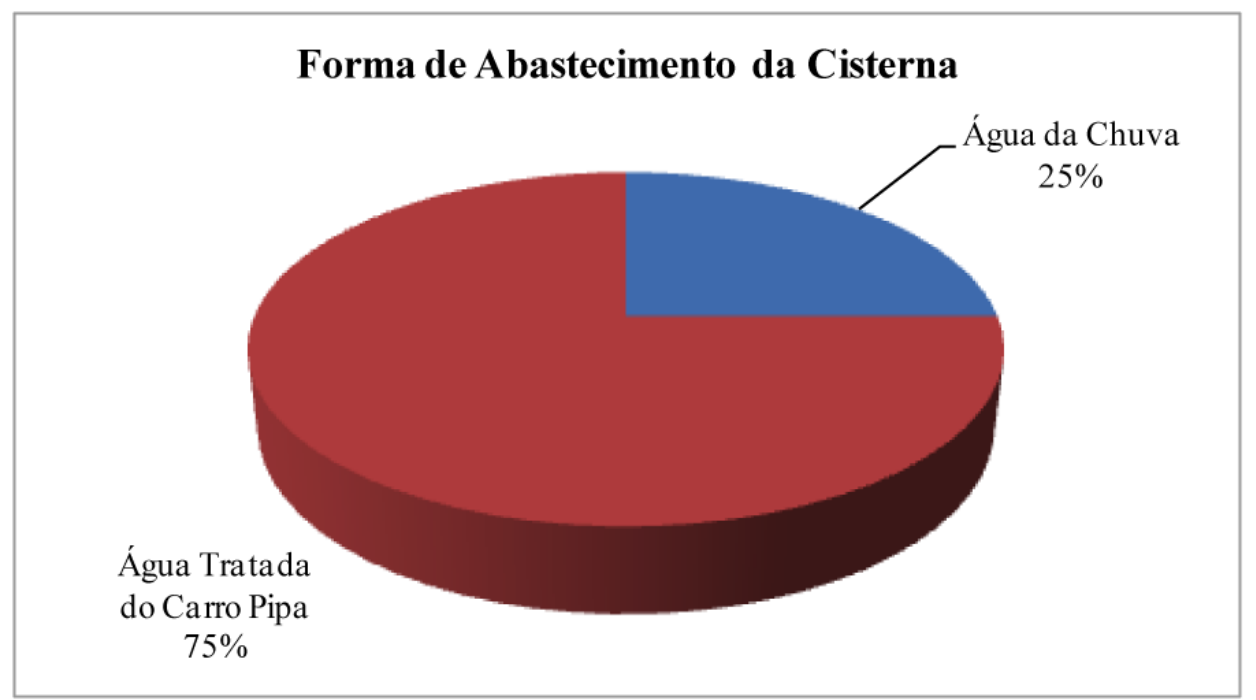


Todos os entrevistados foram unânimes em afirmar que estão muito satisfeitos com a cisterna e que têm convicção de que suas vidas mudaram para melhor.

A maioria das famílias, $70 \%$, disse que a água armazenada na cisterna foi suficiente para o con- sumo das pessoas do domicílio por um período superior a 8 (oito) meses. As demais relataram que a água durou menos tempo, pois forneceram água para os vizinhos que ainda não possuíam a cisterna.

\section{Gráfico 6 - Durabilidade da água}

\section{Durabilidade da água $>8$ meses}

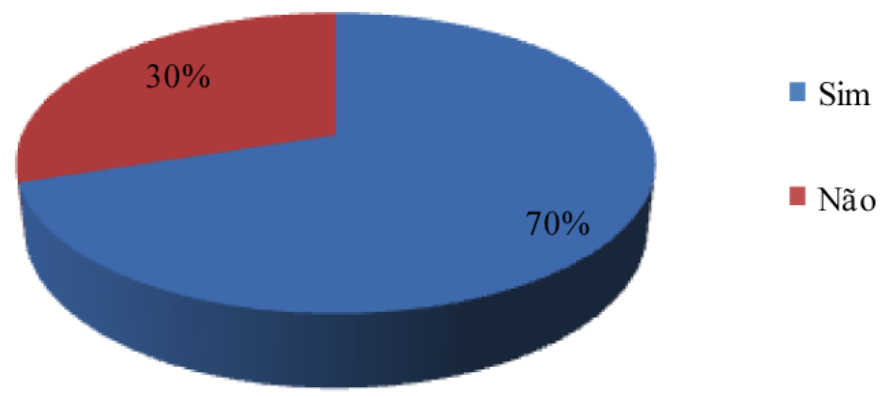

$\mathrm{O}$ acesso à água de qualidade foi o maior benefício apontado pelas famílias. Todos os entrevistados (100\%) afirmaram, categoricamente, que a água de chuva coletada e armazenada na cisterna é de qualidade superior àquela a que eles tinham acesso anteriormente. Muitos relataram que consumiam uma água salobra, barrenta e, até mesmo, contaminada com dejetos de bichos como sapo, rã, besouro e calango.

Acerca da saúde, relataram que, quando consumiam água sem qualidade e de origem duvidosa, eram bastante comuns os casos de doenças nas famílias relacionados à água, tais como: diarreias, vômitos, cólicas etc. E que agora, com a utilização da água coletada na cisterna, tais doenças ocorrem muito esporadicamente.

O questionário também mostrou que antes me- tade das famílias entrevistadas dedicava um tempo significativo à tarefa de buscar água (cerca de 2 horas para cada deslocamento). Em muitos casos faziam mais de um deslocamento por dia, todos os dias da semana.

Situada ao lado da casa, a cisterna permite que as famílias tenham acesso à água de qualidade sem ter que perder tempo ou empreender grandes esforços físicos nos deslocamentos entre a casa e a fonte de fornecimento de água. Por isso, $100 \%$ dos entrevistados apontaram a economia de tempo e esforço como um grande benefício possibilitado pelo uso da cisterna, uma vez que esta permite maior dedicação a outras atividades, como o trabalho rural, ou mesmo ao cuidado das crianças. Todas as famílias entrevistadas afirmaram que a sua renda melhorou, citando como 
principais motivos a sobra de tempo para outras atividades (trabalho na roça, pastoreio, tarefas domiciliares etc.) e a economia dos recursos financeiros, uma vez que não necessitam mais se deslocar até a sede do município para solicitar o carro-pipa, nem pagar pelo custo do abastecimento.

Das comunidades pesquisadas, Sobrado, Pau Preto, Pateiro e Manga são as que ficam mais distantes da sede do município de Juazeiro e por esse motivo são as que mais valorizam a água captada das chuvas e armazenada na cisterna. Nessas comunidades, a presença do carro-pipa é menos frequente, o que explica o fato de a maioria das famílias só utilizar a água da cisterna para beber, uma vez que temem que falte água de qualidade durante a seca.

As comunidades visitadas são carentes e, ainda hoje, vêem-se diante do desafio de conquistar outras melhorias básicas das condições de vida, como água encanada nas torneiras, elevação do nível de escolarização, ampliação das oportunidades de trabalho e renda. Apesar disso, deve se reconhecer que as cisternas constituem-se num melhoramento significativo da vida dessas famílias, que, anteriormente ao Programa, gastavam horas do dia na busca de água para beber, nos períodos de seca.

Para a realidade dos que vivem no meio urbano, com infraestrutura básica de água e esgoto, a cisterna pode ser avaliada como mais um paliativo, uma vez que ainda está longe de ser comparada a um sistema de saneamento básico, porém, para aquelas famílias, a cisterna é um bem de inestimável valor. Todas as cisternas visitadas estavam em locais onde não existe nenhuma outra fonte permanente de água apropriada para o consumo humano, ou seja, o P1MC não constrói cisternas que não sejam realmente necessárias.

Para que as cisternas sejam um meio eficiente de minimizar o desequilíbrio socioambiental do Semiárido, é necessário que o alto envolvimento das famílias na construção das cisternas continue. A sustentabilidade proposta no paradigma de convivência com o Semiárido vai depender dos cuidados diários que as famílias vão ter com as cisternas: usar a água somente para beber e cozinhar; sempre lavar o telhado com a primeira chuva; manter a cisterna fechada; colher a água da cisterna através da bomba de gude; enfim, adotando todos os procedimentos para ter água potável para beber e cozinhar nos períodos de seca, que duram aproximadamente 8 (oito) meses.

Há indicativos de melhoria das condições de vida e de acesso à água para o consumo humano da população estudada devido à facilidade de acesso a uma estrutura simples e eficiente de captação da água da chuva e de aproveitamento sustentável de recursos pluviais. A pesquisa demonstrou que, em algumas das comunidades, a sustentabilidade está ameaçada pela carência de mais cisternas, ou seja, como nem todas as famílias possuem cisternas, as que foram beneficiadas com elas costumam dividir a água do reservatório com outras famílias. Sendo assim, a água irá terminar antes de chegar a nova estação das chuvas, e as famílias continuarão na dependência dos carros-pipa particulares ou dos contratados pela Prefeitura.

Deve-se reconhecer que o P1MC é um grande e importante passo num processo que levará futuramente ao fim da agonia da falta d'água no Semiárido Nordestino. O ponto forte do programa é a metodologia escolhida, que envolve as famílias com a ideia da sustentabilidade, não dando meramente a cisterna, no molde paternalista e assistencialista da "indústria da seca", mas incentivando-as, através de um sistema de mutirão, a compreender a dimensão do trabalho coletivo e do potencial de mudança existente na mobilização social. 


\section{CONSIDERAÇÕES FINAIS}

As condições de vida são produto da sociedade como um todo e estão relacionadas àquilo que uma determinada sociedade realiza para a criação de condições básicas favoráveis à manutenção da vida sã, como a implementação de programas sistemáticos de saúde preventiva e saneamento, e em sistemas de cobertura e assistência universal.

Todavia, essas condições mínimas estão distantes da realidade brasileira, especialmente nas regiões historicamente mais pobres, como visto na revisão inicial do artigo (KERSTENETZKY, 2000; KLIKSBERG, 1997; SACHS, 2004; SANTOS, 1987). Os esforços para diminuir essas profundas diferenças devem se orientar para a integração dos processos de transformação. O exemplo aqui apresentado mostra como a criatividade e a disposição política dos condutores de consórcios sociais podem, com recursos modestos, proporcionar saltos significativos de desenvolvimento, especialmente se a base de partida for muito precária (SEM, 2000). É o caso do programa de cisternas para o Semiárido Nordestino.

É possível perceber o sensível grau de promoção de capital social da região, favorecendo assim seu desenvolvimento endógeno. $\mathrm{O}$ envolvimento das famílias no P1MC contribui para a formação de um novo sujeito coletivo, um cidadão mais consciente e atuante, capaz de criar soluções que melhorem o bem-estar de toda a comunidade. $\mathrm{O}$ PlMC hoje é exemplo do novo padrão de políticas que se baseia na parceria entre órgãos públicos, empresas privadas e organizações da sociedade civil. O fato de o programa ter sido criado por uma ONG, ser posteriormente reconhecido pelo governo e transformado em política pública formal confirma que a relação sociedade-estado passa por mudanças significativas. E cada vez mais a participação da sociedade no processo de desenvolvimento se torna fundamental ao incorporar padrões relevantes na formação de capital social, conforme indicado em literatura consagrada na área (BEDUSCHI e ABRAMOVAY, 2003; DRAIBE, 97; JACOBI, 2000; MOURA, 2002; SOUZA, 1999).

Pode-se concluir que as cisternas rurais não só se apresentam como uma solução efetiva para a sanidade das famílias do Semiárido ao obter acesso à água potável, como também rompem com o padrão político da troca de "votos por água", prática utilizada historicamente pelas lideranças locais, a partir da construção dos açudes em terras privadas. O unânime grau de satisfação medido pela pesquisa indica a importância da cisterna na convivência no Semiárido e a consequente ampliação da participação política dos moradores, que passam a ter crescente grau de liberdade para, por exemplo, melhor escolher seus representantes e acompanhar a gestão dos governos locais.

Há projetos pilotos, atualmente em implantação, de cisternas coletivas. São normalmente construídas sob os círculos de convivência, tais como as praças centrais das pequenas comunidades, com capacidade de armazenamento entre 50 e 100 mil litros, que serão destinadas ao uso coletivo para a criação de pequenos rebanhos comunitários (especialmente caprino-ovinocultura), bem como de hortas e pequenas lavouras coletivas para a merenda das escolas e o consumo dos habitantes da localidade. Tais circunstâncias ultrapassam a dependência histórica de acesso à água potável e, por seu exemplo, podem se tornar um marco na conquista de outras liberdades, contribuindo para a construção de estágios de cidadania mais civilizados para a região e para o país (BODSTEIN e ZANCAN, 2002; FAORO, 1992; FURTADO, 1999).

Diante desse quadro, considera-se esta uma política pública adequada quanto aos meios e quanto aos fins. Ou seja, no caso específico, aquela política onde os órgãos governamentais das esferas federal, estadual e municipal, o setor privado e as 
organizações não governamentais possam contribuir, de forma mais intensiva e articulada, para a disseminação da construção de cisternas rurais na captação de água de chuvas para o consumo humano, onde ela for necessária. Que o programa alcance a meta de 1 milhão de cisternas nos prazos previstos.

$\mathrm{E}$, mais ainda, que os conceitos basilares da articulação da rede de atores, do padrão de planejamento e gestão da política, bem como da filosofia fundamental de promoção do desenvolvimento integrado e sustentável, se tornem modelares. Tanto para a criação e implantação de outras políticas de minimização do estoque de dívida social quanto para a construção da tão desejada modernidade institucional, republicana e democrática no país.

\section{REFERÊNCIAS}

ABRAMOVAY, R. O capital social dos territórios: repensando o desenvolvimento rural. Economia Aplicada, v. IV, n. 2, abr./jun. 2000 .

ANDION, C. Análise de redes e desenvolvimento local sustentável. Revista de Administração Pública. Rio de Janeiro: Fundação Getúlio Vargas, v. 37, n. 5, set.-out. 2003.

Articulação no Semiárido Brasileiro (ASA). Programa de Formação e Mobilização Social para a Convivência com o Semiárido: 1 Milhão de Cisternas Rurais (P1MC) Disponível em: <http://www. asabrasil.org.br>. Acessos em: 1, 12 e 30.ago.2060, 8, 9.set.2006 e 20.out. 2006

BEDUSCHI FILHO, L. C.; ABRAMOVAY, R. desafios para o desenvolvimento das regiões rurais. In: CONGRESSO BRASILEIRO DE ECONOMIA E SOCIOLOGIA RURAL, 41., 2003, Juiz de Fora. Anais... Juiz de Fora: Sociedade Brasileira de Economia e Sociologia Rural, 2003.

BENKO. G. La ciencia regional. Bahía Blanca, AR: Universidad Nacional del Sur, 1999.

BIRNER, A. et al. Local Development initiatives - an intercultural comparison: life strategies and global structure change. Wien, AUT: Institut für Raumplanung und Regionalentwicklung (IRR). Discussion Paper n. 51, 1995.

BODSTEIN, R.; ZANCAN, L. Avaliação das ações de promoção da saúde em contextos de pobreza e vulnerabilidade social. In. ZANCAN, L.; BODSTEIN, R.; MARCONDES, W. B. (Orgs.) Promoção da saúde como caminho para o desenvolvimento local: a experiência em Manguinhos. Rio de Janeiro: Abrasco, 2002.

BROSE, M. Fortalecendo a democracia e o desenvolvimento local: 103 experiências inovadoras no meio rural gaúcho. Santa Cruz do Sul, RS: Edunisc, 2000.

BOISIER, S. E. Sociedad Civil, Participación, Conocimiento y Gestión Territorial. Santiago de Chile, Ilpes, 1997.

BOURDIEU, P. O poder simbólico. Lisboa: Difel, 1989.

BOURDIEU, P. Razões práticas: sobre a teoria da ação. Campinas: Papirus, 1996

CÁRITAS BRASILEIRA, Comissão Pastoral da Terra, Fiani/Brasil. Água de chuva: O segredo da convivência com o Semi-Árido. São Paulo, 2001

CASTILHOS, D. S. B. Capital social e politicas públicas: um estudo da linha infraestrutura e serviços aos municípios do Programa Nacional de Fortalecimento da Agricultura Familiar. 2002. 172 f. Dissertação (Mestrado em Desenvolvimento Rural) - Faculdade de Ciências Econômicas, Universidade Federal do Rio Grande do Sul, Porto Alegre, 2002.

COLEMAN, J. Foundations of Social Theory. Cambridge, MA: Harvard University Press, 1994.

DRAIBE, S. M. Uma nova institucionalidade das políticas sociais? reflexões a propósito da experiência latino-americana recente de reformas dos programas sociais. Revista São Paulo em perspectiva. São Paulo, v.11, n. 4, p. 3-15, 1997.

EMPRESA BRASILEIRA de Pesquisa Agropecuária (Embrapa). Disponível em: <http://www.cpatsa.embrapa.br/doc/ technology/4_7_J_Gnadlinger_p.doc>. Acesso em: 23.ago.2006.

EVANS, P. Embedded Autonomy: States and Industrial Transformation. Princeton, NJ: Princeton University Press, 1995.

FAORO, R. A questão nacional: a modernização. Estudos Avançados, v. 6, n. 14, p. 7-22, abr. 1992.

FERGUSON, A. Nations and civilizations. In: RUNDELL, J.; MENNELL, S. Classical Readings in Culture and Civilization. New York: Routledge, 1988.

FUKUYAMA, F. Trust: The Social Virtues and the Creation of Prosperity. New York, The Free Press, 1995.

FISCHER, T. (Org.) Gestão do desenvolvimento e poderes locais: marcos teóricos e avaliação. Salvador: Casa da Qualidade, 2002.

FLEURY, S. Construcción de ciudadanía en entornos de desigual- 
dad. Revista Instituciones y Desarrollo. Barcelona, n. 16, p. 133$170,2004$.

FRANCO, A. Pobreza e desenvolvimento local. Brasília: Agência de Educação para o Desenvolvimento (AED), 2002.

FURTADO, C. Desenvolvimento e subdesenvolvimento. Rio de Janeiro: Fundo de Cultura, 1961.

FURTADO, C. O longo amanhecer. Rio de Janeiro: Paz e Terra, 1999.

GNADLINGER, J. Colheita de água de chuva em áreas rurais. Juazeiro, BA: Irpaa, 2000.

GODARD, O. et al. Desarrollo endógeno y diferenciación de espacios de desarrollo: un esquema de análisis para el desarrollo local. Estudos Territoriales. Madrid, n. 24, 1987.

GRACIARENA, J. Poder e estilos de desenvolvimento: uma perspectiva heterodoxa. In: BIELSCHOWSKY, R. (Org.) Cinquenta anos de pensamento na Cepal. Rio de Janeiro: Record, 2000. p. 685-713.

JACOBI, P. Políticas sociais e ampliações da cidadania. São Paulo: FGV, 2000. 152 p.

KERSTENETZKY, C. L. Desigualdade e pobreza: lições de Sen. Revista Brasileira de Ciências Sociais. São Paulo, v. 15, n. 42, fev. 2000.

KLIKSBERG, B. O desafio da exclusão: para uma gestão social eficiente. Tradução Giselda Barroso G. A. Sauveur (Coord.); NOGUEIRA, M. A.; AGGIO, A.; Equipe RAP. São Paulo: Fundap, 1997.

LOPES, P. R. C. Alternativas de manejo de solo e água para o Semiárido brasileiro. Disponível em: <www.comciencia.br/reportagens>. Acesso em 16.fev.2006.

MANKIW, N. G. Introdução à economia. Rio de Janeiro: Campus, 1999.

MARTINELLI, D. P.; JOYAL, A. Desenvolvimento local e o papel das pequenas e médias empresas. Barueri: Manole, 2004.

MELO NETO, F. P.; FROES, C. Responsabilidade social e cidadania empresarial: a administração do terceiro setor. Rio de Janeiro: Qualitymark, 1999.

MOURA, M. S. et al. Gestão do desenvolvimento local, tempos e ritmos de construção: o que sinalizam as práticas. Revista de Administração Pública, Rio de Janeiro, v. 36, n. 4, p. 609-626, jul.-ago. 2002.

NASCIMENTO, F. M. F. Histórico das Secas e Programas do Governo no Semiárido: 1534-2004. Rio de Janeiro: Cetem, 2005. (Sé- rie Estudos e Documentos).

NEJAMKIS, F. Capital social y desigualdad social. Un caso: el fondo del Conurbano Bonaerense. Documentos CLAD. Caracas: CLAD, 1999.

NICHOLLS, W. H. Southern tradition and regional economic progress. In: NIJKAMP, P. et al. Regional sustainable development and natural resource use. In: WORLD BANK. Proceedings of the World Bank Annual Conference on Development Economics. Washington: World Bank, 1990.

NALLE JR, C. Desenvolvimento regional e políticas públicas: o caso do Projeto Amanhã da Companhia de Desenvolvimento dos Vales do São Francisco e Parnaíba. 2006. 201 f. Dissertação (Mestrado em Administração de Organizações) - Faculdade de Economia Administração e Contabilidade de Ribeirão Preto, Universidade de São Paulo, Ribeirão Preto, 2006.

OLIVEIRA, G. B. Uma discussão sobre o conceito de desenvolvimento. Revista FAE, Curitiba, v. 5, n. 2, p. 37-48, mai.-ago. 2002.

ORTOLANI, F. Políticas públicas e capital social: o caso dos minidistritos industriais e de serviços de São José do Rio Preto. 2005. 122 f. Dissertação (Mestrado em Administração) - Faculdade de Economia, Administração e Contabilidade, Universidade de São Paulo, São Paulo, 2005.

PALMIER, L. R. Perspectiva da aplicação de técnicas de aproveitamento de água em regiões de escassez. In: DIÁLOGO INTERAMERICANO DE GERENCIAMENTO DE ÁGUAS, 4., 2001, Foz do Iguaçu. Anais... Foz do Iguaçu: 2001

PASSADOR, C. S. A educação rural no Brasil: o caso da escola do campo do Paraná. São Paulo: Annablume, 2006.

PASSADOR, J. L.; CUNHA J. A. C. A formação de alianças e redes interorganizacionais. In PASSADOR, C. S. \& PASSADOR, J. L. (Orgs.) Gestão pública e desenvolvimento no século XXI: caso da Companhia de Desenvolvimento dos Vales do São Francisco e do Parnaíba. São Paulo: Annablume, 2008.

PEREIRA, M. S. Programa de formação e mobilização social para a convivência com o Semiárido Brasileiro: 1 milhão de cisternas rurais (P1MC). Juazeiro, $1^{\circ}$ dez. 2006. Entrevista concedida a Andréa Moreira Duarte Arraes e Helder Libório Feitosa Arraes.

POLETTO, I. Água de Chuva - O segredo da convivência com o semiárido brasileiro, I - Da indústria da seca para a convivência com o Semiárido brasileiro. Brasília: Cáritas Brasileira, 2001. p. $16-24$.

PROGRAMA das Nações Unidas para o Desenvolvimento (PNUD). Desenvolvimento Humano e IDH. Produzido pela Organização das Nações Unidas. Disponível em: <http://www.pnud.org.br/idh>. Acesso em 20.mar.2006 


\section{CLAUDIA SOUZA PASSADOR E JOÃO LUIZ PASSADOR}

PUTNAM, R. Comunidade e democracia: a experiência da Itália moderna. Rio de Janeiro: Fundação Getulio Vargas, 1996.

ROUTledGE, B.; AMSBERG, J. Endogeneous Social Capital. Pittsburgh, Carnegie Mellon University, 1996 (Mimeo.)

RODRÍGUEZ, M. P. Gestão social do território: experiências no estado do Maranhão. Brasília: IICA, 2005.

SACHS, I. Desenvolvimento: includente, sustentável, sustentado. Rio de Janeiro: Garamond, 2004.

SANTOS, W. G. dos. Cidadania e justiça: a política social na ordem brasileira. 2. ed. São Paulo: Paulus, 1987.

SANROMÀ, M. Las redes ciudadanas. La Factoría. Colomers, n. 8, fev. 1999.

SARAVIA, E. A nova administração para o desenvolvimento. In: CONGRESO INTERNACIONAL DEL CLAD SOBRE LA REFORMA DEL ESTADO Y DE LA ADMINISTRACIÓN PÚBLICA, 9., 2004, Madrid. Anais... Madrid: Centro Latinoamericano de Administración para el Desarrollo, 2004.

SEN, A. Desenvolvimento como liberdade. São Paulo: Companhia das Letras, 2000.

SILVEIRA, C.; REIS, L. C. (Org.) Desenvolvimento local: dinâmicas e estratégias Rio de Janeiro: Ritz, 2001.

SINGER, P. Introdução à economia solidária. São Paulo: Perseu Abramo, 2002.
SOUZA, M. L. Desenvolvimento de comunidade e participação. 6. ed. São Paulo: Cortez, 1999.

STÖHR, W. B. Global challenge and local response. Initiatives for economic regeneration in contemporary Europe. London: Mansell, 1990.

TENDLER, J. Bom governo nos trópicos: uma visão crítica. Brasília: Enap, 2002

TORCAL, M.; MONTERO, J. R. Facets of social capital in new democracies: the formation and consequences of social capital in Spain. Chicago: Kellog Institute. Working paper nº 259, 1988.

TOMAZ, P. Aproveitamento de água de chuva para áreas urbanas e fins não potáveis. São Paulo: Navegar Editora, 2003.

VÁZQUEZ BARQUERO, A. Desarrollo local: Una estrategia de creación de empleo. Madrid: Pirámide, 1988.

VEIGA, J. E. Desenvolvimento sustentável: o desafio do século XXI. Rio de Janeiro: Garamond, 2005.

WOLFE, M. Abordagens do desenvolvimento: de quem e para quê? In: BIELSCHOWSKY, R. (Org.) Cinquenta anos de pensamento na Cepal. Rio de Janeiro: Record, 2000.

VILLA, M. A. Vida e morte no sertão, São Paulo: Ática, 2001.

ZAPATA, T. et al. Desenvolvimento local: estratégias e fundamentos metodológicos. In: SILVEIRA, C. M.; REIS, L. C. Desenvolvimento local: dinâmicas e estratégias. Rio de Janeiro: D 